\title{
Approaches on primary log breakdown process
}

\author{
Hızır Volkan GÖRGÜN*, Öner ÜNSAL \\ Istanbul University, Faculty of Forestry, Istanbul, TURKEY \\ *Corresponding author: volkan.gorgun@istanbul.edu.tr
}

Received Date: 11.01.2017

Accepted Date: 26.10 .2017

\section{Abstract}

Aim of study: Innovations of "primary breakdown process" which is the first step of log sawing process were evaluated with their reasons and results.

Area of study: Primary log breakdown process were investigated with products of domestic and foreign log sawing machine manufacturers, scientific studies and operations at especially foreign sawmills.

Material and Methods: Log quality assessment techniques, sawing techniques and sawing machines were compared with conventional methods.

Main results: Losses during the log sawing can be minimized with small but effective innovations. However, domestic sawmills which are foreign-dependent on especially raw material (log) should consider their financial situations while taking an investment decision.

Research highlights: Domestic sawmills can try "non-destructive evaluation techniques" for required evaluations while before, during and after the primary breakdown process.

Keywords: Log, Primary Breakdown Process, Yield, Sawing, Band Saw

\section{Birincil tomruk biçme işlemiyle ilgili yaklaşımlar}

\section{Özet}

Çalışmanın amacı: Tomruk biçme işleminin ilk aşaması olan "Birincil tomruk biçme prosesiyle ilgili geliştirilen yeniliklerin, sebepleri ve sonuçlarıyla birlikte irdelenmiştir.

Çalışma alanı: Yerli ve yabancı tomruk biçme makinesi üreticilerinin ürünleri ve bilimsel çalışmalar ile özellikle yurtdışında faaliyet gösteren kereste fabrikalarında prosesin bu aşamasında yapılan yenilikler ele alınmıştır.

Materyal ve Yöntem: Tomruk kalitesinin değerlendirme yöntemleri, kullanılan biçme teknikleri ve biçme makinelerinin incelenmiş ve geleneksel yöntemlerle karşılaştırılmıştır.

Sonuçlar: Tomruğun işlenmesinde yaşanan kayıplar, ufak ama etkili yeniliklerle en aza indirgenebilir. Ancak tomruk bakımından büyük oranda dışa bağımlı olan kereste endüstrisi, bu müdahaleleri yaparken finansal durumlarını göz önünde bulundurmaları gerekmektedir.

Araş̧tırma vurguları: Yerli üreticilerin bu proses öncesi, sırası ve sonrasinda gerekli incelemelerin yapabilmesi adına alternatif yöntemlerden tahribatsız değerlendirme yöntemlerinin değerlendirmesi tavsiye edilmektedir.

Anahtar kelimeler: Tomruk, Birincil Biçme Prosesi, Randıman, Biçme, Şerit Testere 


\section{Introduction}

Wood is a very valuable material. Wood and it's raw material (tree) have important status for ecologic cycle of nature and also economic cycle of manufacturers. Therefore each processing stage of wood should be evaluated carefully. Each evaluation should be made according to raw material and fulfilled market requirements.

Solid wood processing starts with harvesting from forest. Long trunks are bucked to $3 m-6 m$ length (Bucking). Logs are sorted according to some features e.g. length, diameter, specie, quality etc. (Sorting) and then barked (Barking). In sawmill, there are two main sawing stages: Primary and Secondary Log Breakdown.

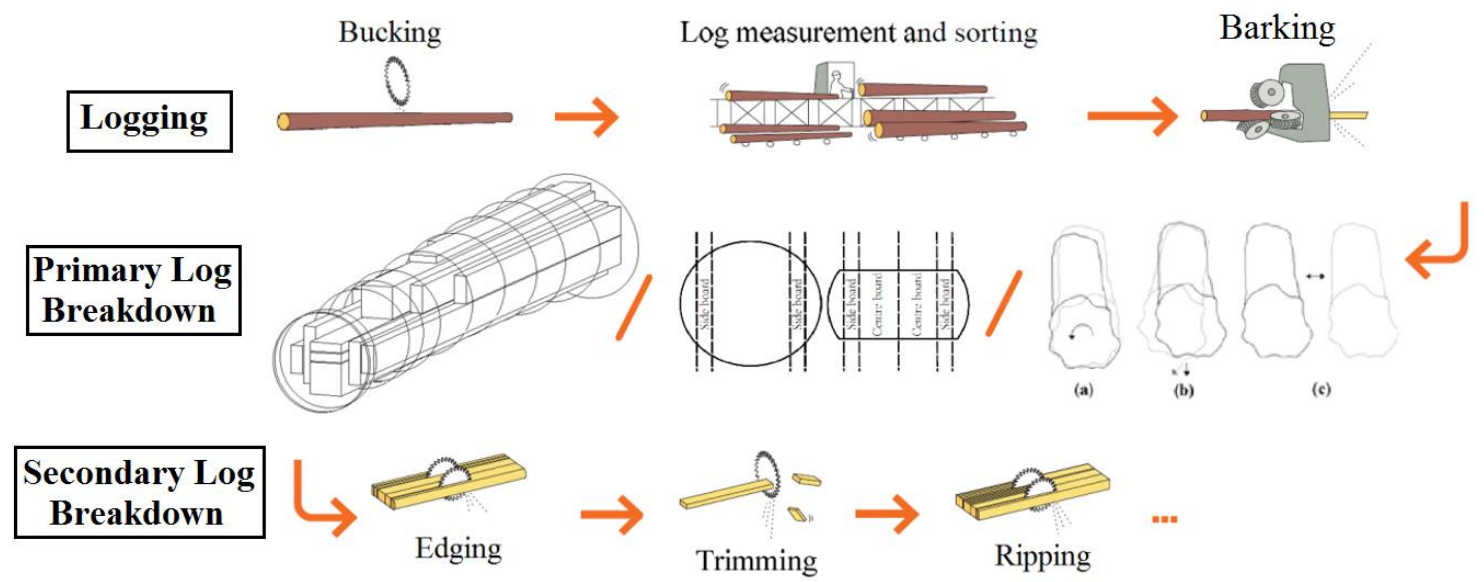

Figure 1. Lumber production stages in sawmills (Illustration was created from thesis of Berglund (2014))

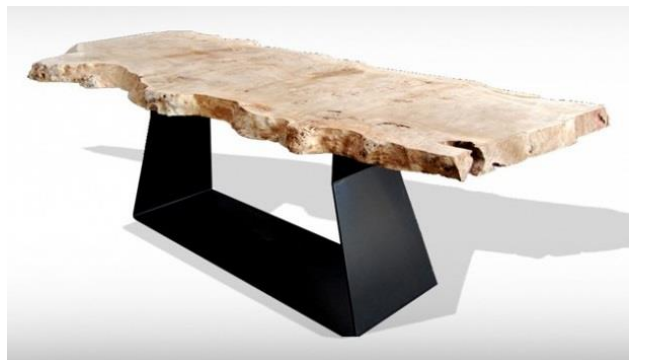

Figure 2. Natural wooden product (table) without secondary breakdown process (URL1, 2016)

Primary log breakdown process has many variables such as log properties, operator behavior, sawing equipment and techniques and customer requirements etc. Even if logs have many differences like taper, curve shapes, defects as knot, split etc. Although
Cylindrical-shaped logs or smooth-edged and big-sized cants are cut to slabs or foursquared lumbers in primary log breakdown process. But the outputs in this process are usually regarded as semi-finished and need some additional to undergo sawing process like edging, trimming, planing etc. defined as secondary breakdown (Figure 1). Defects such as wane, split etc. are removed from the material in this process.

However, some manufacturers do not need secondary breakdown process and utilize the pieces as "natural wooden products" (Figure 2). 
notch or groove made by a saw), sawing variation, product mix, management decision making, maintenance equipment and sawing method (Steele, 1984). Knowing the variables that affects lumber recovery in general can unravel the factors present in a specific mill. Therefore the optimization of the process requires accurate measurement, positioning and transport of logs, cants and boards during processing, as well as optimum sawing decisions and narrow kerf accurate sawing (Szymani, 1995).

\section{Log properties}

Log as a natural material has many features. Almost all logs can be different due to heterogeneous structure, species diversity, defects. Each feature effects all sawmill operation factors such as sawing machine types, saw blade properties, cutting patterns etc. Therefore small sawmills usually accepts logs only limited criteria such as coniferous species, max. $25 \mathrm{~cm}$ in diameter etc., while bigger sawmills sort the logs according to common features that are usually tree species, diameter, length and quality.

Sorting is useful stock tracking and to find suitable log for production. Many large sawmills invest stock tracking and automatic log sorting systems (Figure 3).

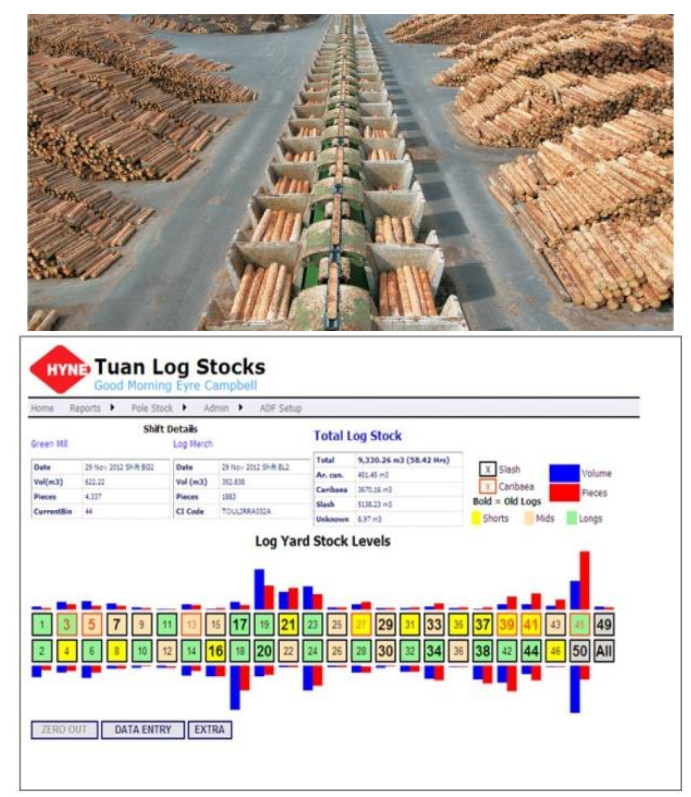

Figure 3. (Above) Classification with high sorting conveyor in logyard (Schmidt, 2009),
(Below) Stock tracking system (Campbell, 2013)

All log features and also potential defects should be determined and measured before sorting and sawing. Especially determining the size and location of defects is crucial to evaluating the potential yield and value of logs (Berglund, 2014). Because $\log$ characteristics and defects vary in size, shape and type, making them difficult to identify and classify. Defects, such as sawn-knot stubs, rotten knots, surface distortion, holes, cracks, gauges, branch sprouts, swelling, worm holes and animal damage are imperfections that decrease wood value and utility (Thomas and Thomas, 2013).

Non-destructive evaluation (NDE) methods that defined as determining physical and/or mechanical properties of a material without defects or changing end-use properties by Pelerin and Ross (1994) have been used in wood industry. Visual grading, one of the NDE technique, is used in sawmills. It considers surface properties of a log like knot diameter, outer shape, annual rings, checks etc. However Sohrabi (2013) indicates that most sawmills optimize their log cutting processes by only considering the external shape of logs and the information regarding the desired final products with no knowledge about any internal defects in the logs. Because the defects are threedimensional, they continue into the log and change internal properties. Berglund (2014) indicates that since the position of internal features such as knots cannot be precisely determined, it is only possible to maximize the volume of the sawn timber produced.

All information about the external and internal features of each sawlog required to be obtained in order to improve the quality and value of the sawn products. Because of this reason, visual grading technique should be improved or other NDE techniques should be tried for the best yields.

Conventional way to determine the quality of a log is by inspecting surface and ends visually. The rules defined by standards (e.g. TS 276 (1980)) are based on measuring log and defect shape. Volume, distortion and only visible defects on surface as knot diameter, check length, rot area etc. can be 
evaluated by the standards. But logs and also defects are three-dimensional, visible properties cannot evaluate effectively internal properties. Only a few standards as BS 4978 (2007), improved alternative prediction method to evaluate inner defects for grading lumbers. In this standard, threedimensional knot volume is estimated through visible diameter of knot and annual ring direction. Lumbers are classified by measuring of projection area of knot volume on cross-section (Figure 4) (Görgün, 2013).

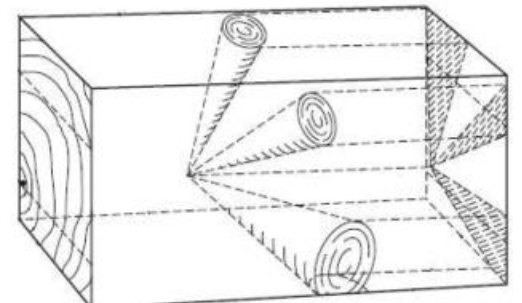

Figure 4. Example of knot estimation in BS 4978 standard (2007)

Scientific studies on NDE methods continue to determine for more and "deeply" information about $\operatorname{logs}$ and defects (Figure $5)$.

(a)

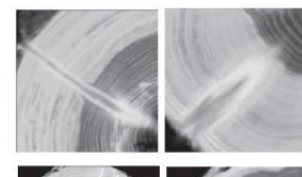

(b)

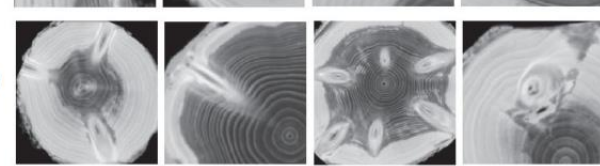

Figure 5. Some images from computed tomography about knot appearance inside logs (a- Scots Pine, b- Norway Spruce) (Johansson, 2013)

\section{Sawing process}

Process is a whole with raw material, equipment, production techniques and employees. Therefore choosing the best option in primary log breakdown process is related to $\log$ properties, customer requirements, sawmill technology and employees.

At this stage, sawmill operator should decide the best option based on these variables. If information about the external and internal features of each sawlog can be obtained, the whole breakdown process e.g. sawing, trimming and edging boards can be simulated and optimized according to requirements.

\section{Decision making process for sawing}

The decisions of sawmill operator significantly affect lumber recovery. The heterogeneous structure of the raw material require the sawing operators to make thousands of decisions every day. Fatigue, lack of knowledge, ability or carelessness can cause to make improper decisions. In some cases, so many variables must be considered in such a short time that even the best operator finds it impossible to make optimum decisions (Steele, 1984). For example, generally sawmill products can be classified into two categories: High-value products, especially high quality lumber pieces and low-value products, such as slabs, wood chips, saw dust and residual bark which were described "waste" whilom. Developing technology created occasion to low-value products to supply other sectors of the forestry industry, including the pulp and paper, pellet and biofuel industries (Sohrabi, 2013). The most important thing at this stage is which product group will be chosen. When the management policy was defined on this point, other sawing decisions come into the forefront.

Although there are a large number of classifications for log sawing patterns, they can be categorized into three general groups. "Live-sawing" is sawing with a breaking cut, "Cant (prism) sawing" is sawing side boards and slabs at first and sawing other side boards and centre boards with turning the prism $90^{\circ}$. The sawing stage of cant sawing is typically broken down into two separate steps. First, logs are cut into large flat pieces called cants. The cant will be broken down into lumber pieces through a specific sawing machine such as gang saw. In addition to the resulting lumber pieces, the remaining parts called flitches, are produced. These flitches may go on to the edger, trimmer or re-sawing stages in which dimensional lumber pieces can be produced (Sohrabi, 2013). In Swedish sawmill industry, this process standardized according to dimensions and sawn place 
from log. Thinner boards (side board) are sawn outer area of log, while thicker boards (center board) are sawn middle area of $\log$ (Figure 6) (Fredriksson, 2014). In sawmills using band saw, products obtained at second saw have better edge quality. Circular saw can generate saw kerf on the boards.

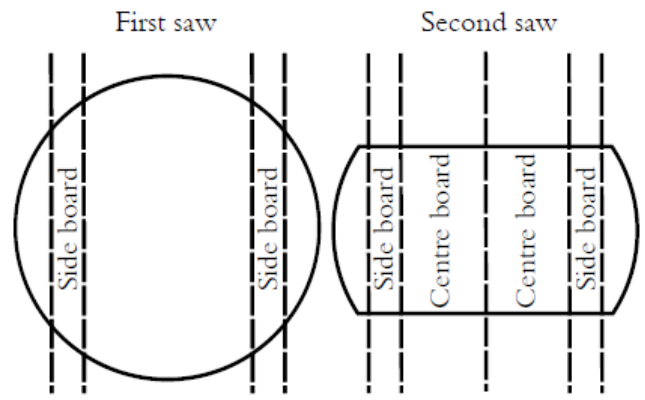

Figure 6. Cant sawing process in Sweden (Fredriksson, 2014)

"Quarter sawing" is sawing logs to obtain lumber with angel of annual rings to wider surface on cross-section is bigger than $45^{\circ}$. Each cutting method has its own distinct advantages and disadvantages based on its applicability to large or domestic sawmills, production speed, production cost, ability to produce high quality lumber, shape of logs and degree of mechanization (How et al., 2007).

Developments in sawmilling technology enable computers to make many of these difficult decisions (Steele, 1984). Cutting optimizer, a computer program, then calculates the best cutting pattern among all available patterns, the one that results in maximum lumber value (or another purpose) with reference to a set of lumber prices (known as a "price list") (Sohrabi, 2013).

The programs use mathematical models to calculate best computer-aided sawing strategies for primary log breakdown optimization. The most of models involving sawing optimization use "Dynamic Programming" principles (Tejavibulya, 1982; Todoroki and Ronnqvist, 1997; Reinders and Hendriks, 1989). In addition, heuristic algorithms such as the "Genetic Algorithm" are also being used (Cook and Wolfe, 1991; Sohrabi, 2013). A number of simulation software packages such as SIMSAW (Singmin and NTRI, 1978), Best Opening
Face (BOF) (Lewis, 1985), AUTOSAW (Todoroki, 1990), SAW3D (Zeng, 1991), SAW3DG (Zeng, 1995), SAWSIM (URL2, 2006) etc. were used to increase lumber recovery and to improve management decision-making stage (Figure 7).

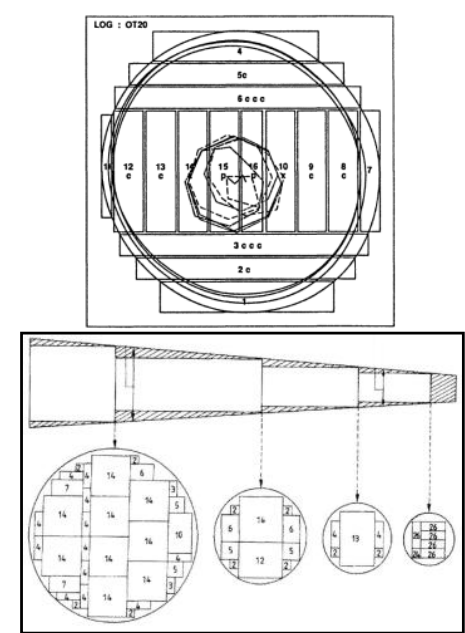

Figure 7. Sawing possibilities from cross section (Above: Todoroki, 1990) and from length and cross section (Below: Reinders and Hendriks, 1989).

Each program has distinctive capabilities with regards to $\log$ representation, internal defect considerations and the flexibility of the log breakdown procedures (Todoroki and Ronnqvist, 1999).

One of these programs, The Best Opening Face (BOF) system is based on the fact that the position of the first saw line determines the lumber recovery from the $\log$ and that proper placement of this saw line can assure optimum lumber recovery. Results showed that BOF increases lumber yield by shifting the pattern within the log, giving a better geometric fit of lumber (rectangular solids) inside the $\log$ (truncated cone) (Figure 8) (Lewis, 1985). 


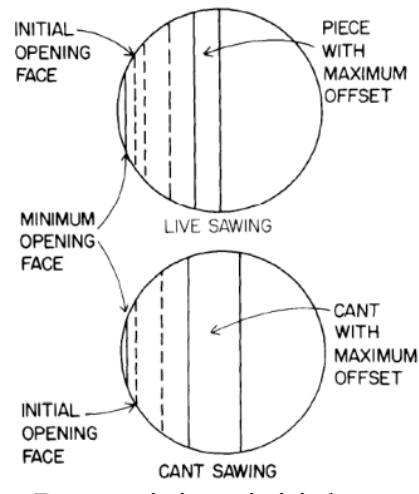

Figure 8. Determining initial opening face for offset sawing in BOF (Lewis, 1985).

In Turkey, "KORKUT Yield Optimization Program" was developed with using maximum yield theory and its equations. The results of the study showed that the yield with optimization program can make important changes in the income for the user and supply countrywide economical development (Figure 9) (Korkut, 2003).

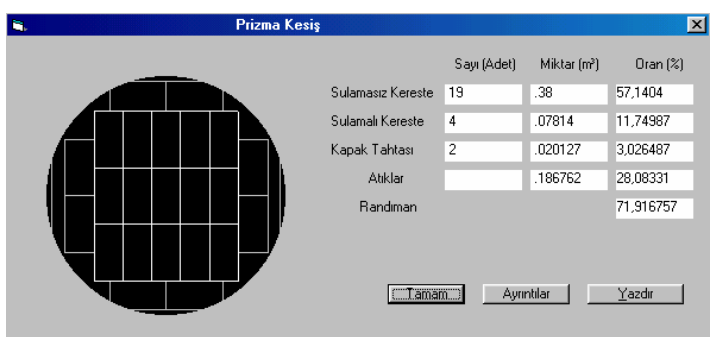

Figure 9. An output of KORKUT Yield Optimization Program (Korkut, 2003)

Also software packages helped to show sawing process and it gave some advantages. Previously operators had been choosing minimum diameter for truncated cone shape of $\log$ due to lumber length problem. As shown in Figure 10., actually maximum diameter is more proper in terms of utilizing all volume.

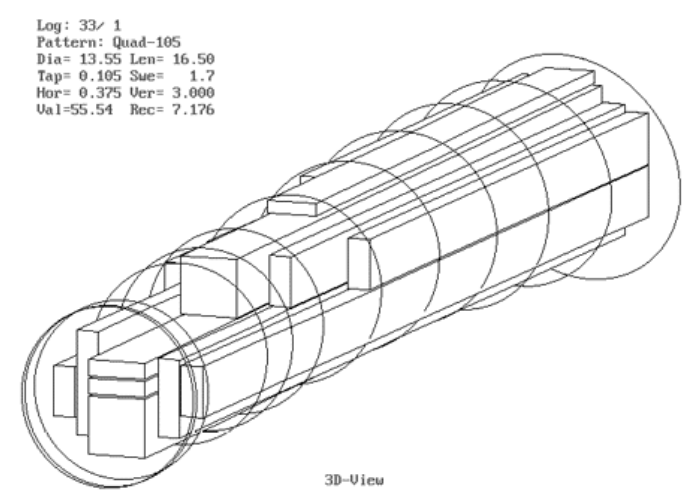

Figure 10. Three dimensional sawing pattern according to maximum diameter choice (URL2, 2006)

Many programs suppose the logs as if its cross-section is circular, the surface is smooth and free from defects. But $\log$ as a natural material can has several distortion and defects. "The Marcus Wallenberg Prize 2016" winner Alexander Katsevich and Microtec CEO Federico Giudiceandrea (2011; 2012) developed CT scanner and Maxicut sawing optimization program combination to solve this problem (URL3, 2016). It is indicated that a potential increase of 20 to 25 percent is possible if all the advantages of having access to the internal features of the timber are realized with band speed of up to 180 meters per minute (Figure 11) (URL4, 2016). In this technology, log is scanned to detect defects (a) (At Figure 11, each color symbolizes different defect: Blue is fissure, red is dead knot while yellow is sound knot) Then proper sawing pattern is positioned on right angle in the log according to maximization of value, yield etc. (b). And finally quality grade and price of each lumber is determined (c).

At the second stage, positioning is the most critical process to optimizing output. Berglund (2014) indicates that log position effects yield according to $\log$ defects or produced lumber properties. If the $\log$ is positioned in such a way that it results in sawn timber with good appearance or high strength, the value of the sawn timber and the sawmill profitability can be increased. 
(a)

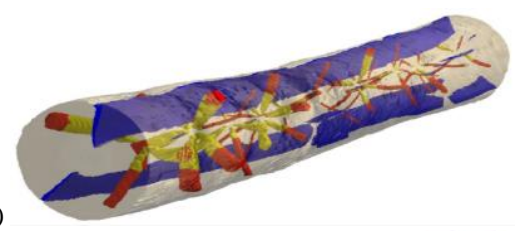

(b)

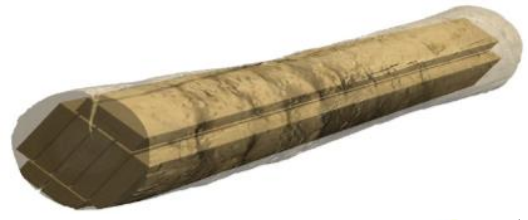

(c)

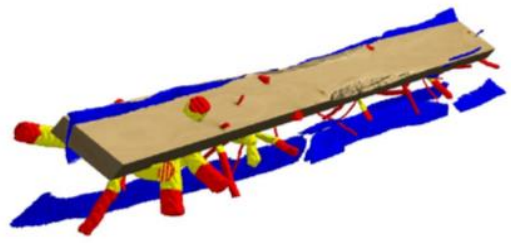

Figure 11. Determining optimum sawing pattern by using defects (URL4, 2016)

\section{Sawing techniques and equipment}

The log position can be aligned with saw in three different ways, by rotational offsets (a), skew (b) and parallel (c) as shown in Figure 12.

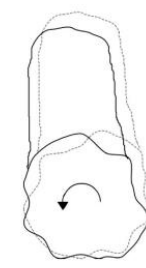

(a)

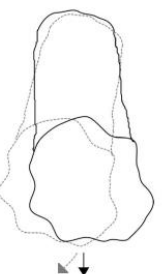

(b)

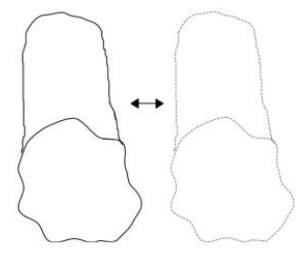

(c)
Figure 12. The different ways to position a log in primary breakdown process (Berglund, 2014)

In sawmills, log is positioned by log carriage in band saws, while log conveyor or cylinders in circular saws as shown in Figure 13.
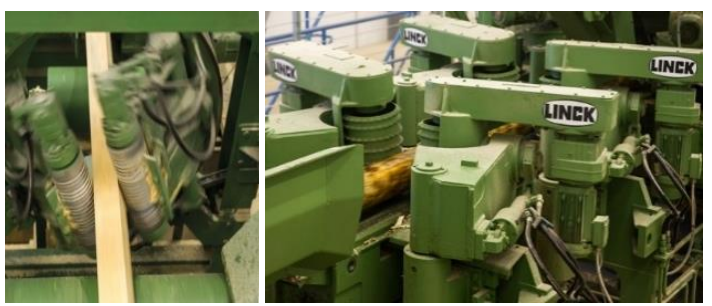

Figure 13. Automatic log positioning machines for rotating (Left), skewing and parallel displacement (Right) (URL5, 2016)
Some shape defects do not allow using standardized sawing diagrams and equipment. Therefore, advanced sawing methods and equipment have been grown with technological developments. In some sawmills, angle of bandsaws and $\log$ carriages can change which more sensitive to adjust.

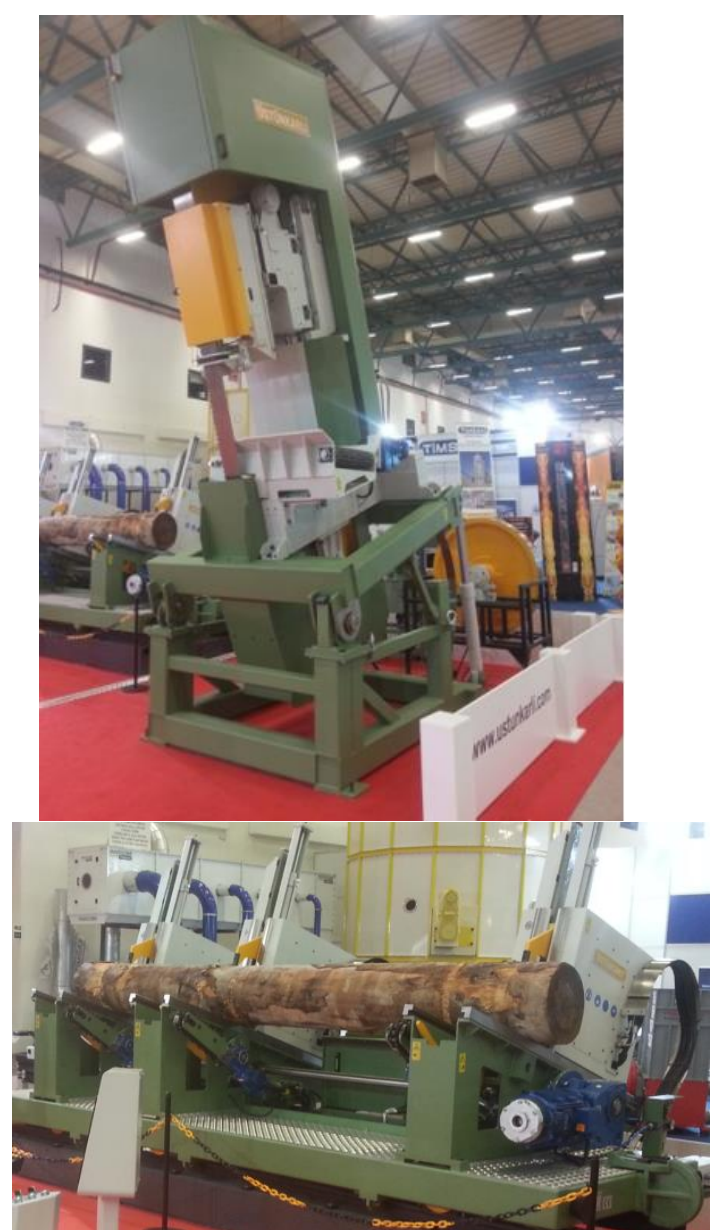

Figure 14. Band saw and log carriage with different angles (Photo by H.V. Görgün at TÜYAP - Wood Processing Machinery Fair 2015)

"Curve sawing" technique were developed in Scandinavia, follows the natural curvature (or sweep) of the log and results in greater yield from each cant (Szymani, 1995). This means that the saw blades follow the curvature of the log with conveyor as illustrated in Figure 15. 
(a)

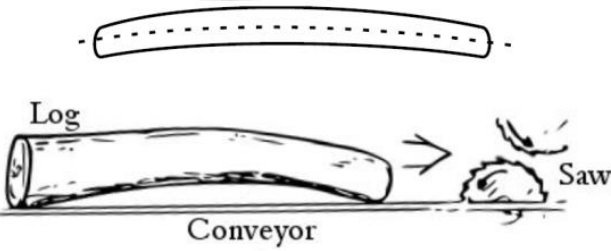

Figure 15. Curve sawing process: (a) shows view above the $\log$ and (b) shows horns down position, the log is positioned in front of the first saw so that the largest curvature is directed upwards (Fredriksson, 2014).

Moreover, this technique can be performed only with movable hooks on $\log$ carriages in the bandsaws (Figure 16).

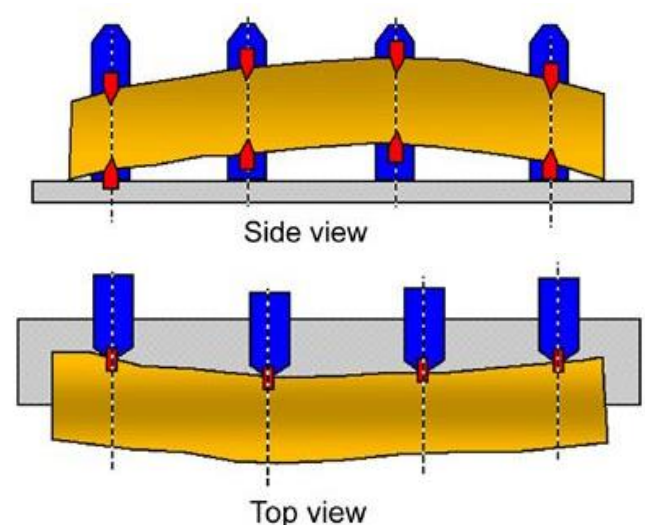

Figure 16. Curved log handling in band saw (URL6, 2016)

Although constitutively the bandsaws have two type (horizontal and vertical), only Robichaud (1975) compared their characteristics. It is reported that kerf and sawing precision values for four horizontal and four vertical bandsaws were compared and found no significant difference between the machines (Steele et al., 1992). However, it can have some differences while performing the sawing process. For example, cracking is reported (Özen, 1982) nearly at the end of log while sawing thick boards with vertical band saws and some supports can be used (Figure 17). But horizontal bandsaws don't need supporters because of pieces can be get without "falling" (Figure 18).

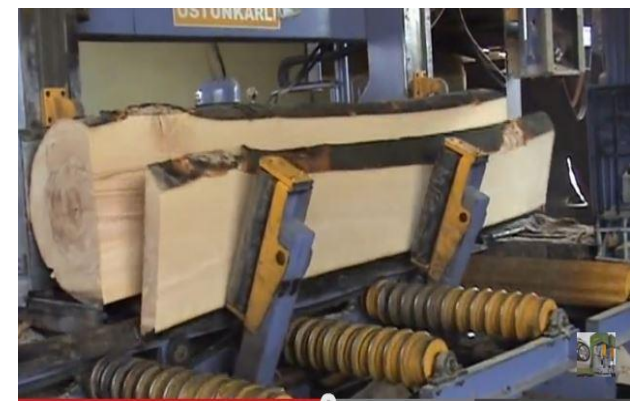

Figure 17. Supporters for slabs in vertical bandsaws (URL7, 2016)

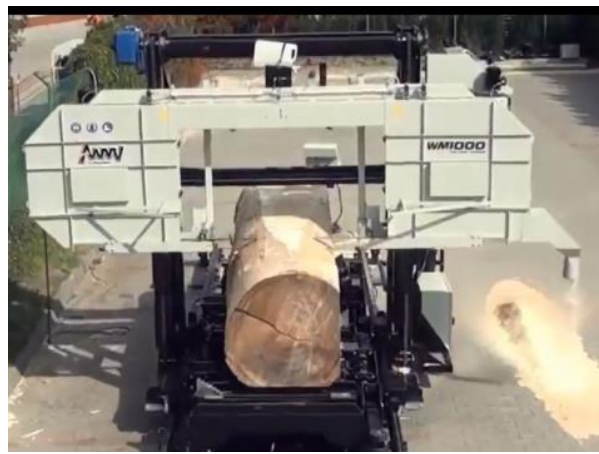

Figure 18. Horizontal log sawing machine (URL8, 2016)

Although Robichaud (1975) says the exact opposite, with technological improvements, some differences of horizontal band saws can be summarized that:

- More sensitive to adjust the $\log$ and to take the boards,

- More effective curve sawing process with mobile wheels,

- Thinner boards can sawn with welladjusted and well-whetted saws (Burdurlu, 1995),

- Easier to setup and use in sawmills or forest areas,

- Thinner blades can be used due to less sawing strains etc.

Saw blade thickness has important role in primary log breakdown process, because it affects quantity yield. Band saw is thinner than circular saw and frame saw, which results less saw kerf width and a greater quantity yield. When considered the energy, net cutting power of sawing is in proportion with the saw kerf width, the individual net energy normative are also smaller. With proper saw blade preparation and corresponding parameters of sawing, the 
quality of the sawn surface is better and there is significantly less edge tear-out than would be the case if the frame saw were used (Istvanic et. al, 2009).

Nevertheless, major considerations in any attempt to optimize saw design are saw vibration and stability during operation. At present, the trend is to apply high "strain" and to use computerized monitoring of band saw displacements and control of feed speed. The CETEC bandmill incorporates a double column narrow configuration bandmill with an automatic control of positioning and tensioning of the saw (Szymani, 1990).

From a sawmill perspective, more capacity and productivity increment can be required. Some sawmills using band saw can use two-sided blades (Figure 19) which enables sawing while log carriage return. On the other hand, capacity can be increased with adding second band saw to behind (tandem) or to near (twin). But process of these machines have minor differences. When the first board was sawn at first band saw in tandem, sawing the second board wouldn't have finished. It waits moving away of second board on conveyor. During the waiting, $\log$ moves front and back repeatedly to prevent burning board surface (Figure 20). Additionally some equipment for increasing capacity can be added as seen in Figure 21. They can gain extra time edging and trimming in primary breakdown process.

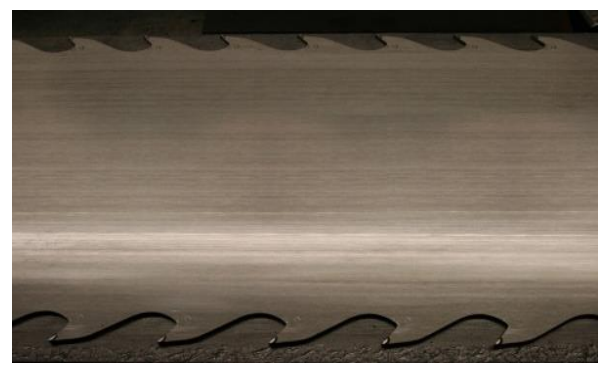

Figure 19. Two-sided band saw
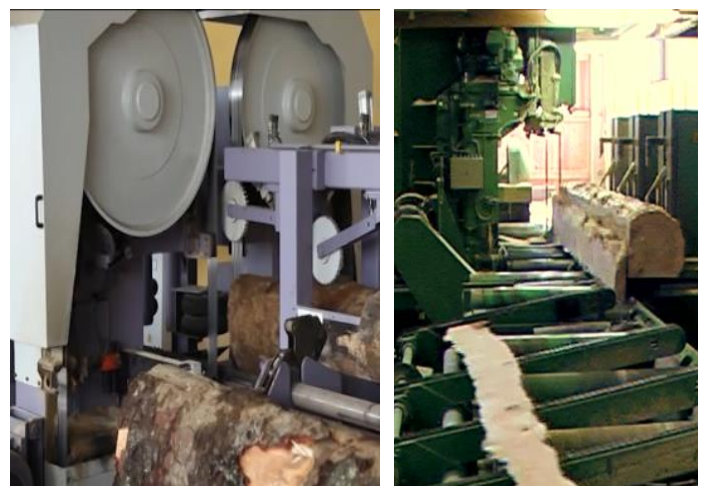

Figure 20. Double Bandsaws Types (Left) Twin (URL7, 2016), (Right) Waiting in Tandem (URL9, 2016)

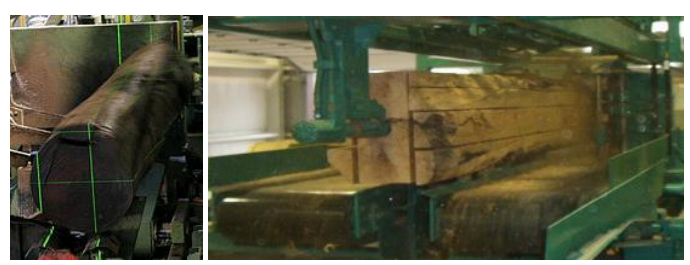

Figure 21. (Left) Saw guides to predetermine saw line with laser, (Right) HELLE Scragg With Vertical Edgers (URL10, 2016)

\section{Conclusion}

Log is invaluable raw material and its ecological and economical importance has been increasing day by day and also this situation has been reflecting on solid wood industry. Thereby primary log breakdown process that can be described as first step of log sawing processing has been becoming more and more important.

Engineers or operators can evaluate some techniques and equipment mentioned in this study according to circumstance. For Turkey, prices and supply problems seriously affect to perform all of them. And company owners or decision-makers don't invest in all cases according to technical truths. Whereas quality and yield should be in the first plan together with economic developments. For example, a limited increment (e.g. \%3) at yield can provide a remarkable recovery. It can be easily explained when comparing the prices. Pine sawlog price is app. $300 € / \mathrm{m}^{3}$, while a Teak is app. $14000 € / \mathrm{m}^{3}$ in Turkey.

However a few large-scale sawmills at West Black Sea Area in Turkey have been increasing the investments and they can 
compete with other global companies at especially with some hardwoods and domestic tree species. But these investments and developments should start from lower level and should be improved step by step due to financial situation.

Many NDE systems have been developed and implemented for the NDE of wood products in a myriad of applications before, during, and after processing from logs to finished wood products (Dündar and Divos, 2014). But with this technology, it has been studied especially on prediction of lumber properties in Turkey (Dündar et. al, 2012; Kol and Yalçın, 2015; İçel and Beram, 2016). However it is suggested that these studies can continue with accumulation of knowledge for aiding decision-making period in primary log breakdown process.

\section{References}

Berglund, A. (2014). Efficient utilization of sawlogs using scanning techniques and computer modelling. Doctoral thesis, Luleå University of Technology, Skellefteå, Sweden.

BS 4978 (2007). Visual Strength Grading of Soft Wood - Specification. British Standards Institution, United Kingdom.

Burdurlu, E. (1995). Lumber Industry and Drying, Bizim Büro Printing House.

Campbell, E. (2013). Simulation of sawmill yields at Hyne Tuan Pine Mill, Dissertation Report of ENG4112 Research Project, Faculty Health, Engineering \& Sciences University of Southern Queensland, Australia.

Cook, D.F., Wolfe M.L. (1991). Genetic algorithm approach to a lumber cutting optimization problem. Cybernetics and Systems, 22 (3), 357-365.

Dündar, T., Divos, F. (2014). European Wood NDT \& NDE Research and Practical Applications. Eurasian Journal of Forest Science, 2 (1), 35-43.

Dündar, T., Kurt, Ş., As, N., Uysal, B. (2012). Nondestructive Evaluation Of Wood Strength Using Thermal Conductivity. Bioresources, 7, 33063316.

Fredriksson, M. (2014). The value of wood.
Doctoral thesis, Luleå University of Technology, Skellefteå, Sweden.

Giudiceandrea, F., Ursella, E., Vicario, E. (2011). A high speed CT scanner for the sawmill industry. In Proceedings of the 17th International Non Destructive Testing and Evaluation of Wood Symposium, University of West Hungary, Sopron, Hungary.

Giudiceandrea, F., Ursella, E., Vicario, E. (2012). From research to market: a high speed CT scanner for the sawmill industry. In Bonfiglio, A., Magenes, G., Pietrabissa, R., and Gabriella, M., editors, pages 159-169, Bressanone, Italy. XXXI Scuola Annuale di Bioingegneria.

Görgün, H.V., (2013). Determination Of Bending Strength And Modulus Of Elasticity In Wooden Beam With Nondestructive And Destructive Test Methods. Master's Degree Thesis, Institute Of Science And Technology Istanbul University, Istanbul, Turkey.

How, S.S., Sik, H.S., Ahmad, I. (2007). Review on six types of log cutting methods in various applications: part 1 . Forest Research Institute, (45), Malaysia.

Ištvanić, J., Beljo Lučić, R., Jug, M., Karan, R. (2009). Analysis of factors affecting log band saw capacity. Croatian Journal of Forest Engineering, 30 (1), 27-35.

İçel, B., Beram, A. (2016). Non-destructive evaluation methods that can be used for the determination of some properties of historical wooden structures. Turkish Journal of Forestry, 17 (2), 201-207.

Johansson, E. (2013). Computed tomography of sawlogs knot detection and sawing optimization. Doctoral thesis, Luleå University of Technology, Skellefteå, Sweden.

Kol, HŞ., Yalçın, İ. (2015). Predicting Wood Strength using Dielectric Parameters. BioResources, 10 (4), 64966511.

Korkut, S. (2003). Researches On Optimization In Lumber Production. Doctoral Thesis, Institute of Science, Istanbul University, Istanbul, Turkey.

Lewis, D.W. (1985). Sawmill simulation and the best opening face system: a 
user's guide. US Department of Agriculture, Forest Service, Forest Products Laboratory.

Özen, R. (1982). Lumber Industry Lecture Note (Unpublished). Faculty of Forest, Karadeniz Technical University, Trabzon, Turkey.

Pellerin, R.F., Ross, R.J. (2002). Nondestructive Evaluation of Wood. Forest Products Society Publication, Madison, USA, 1-892529-26-2.

Reinders, M.P., Hendriks, T.H.B. (1989). Lumberproduction optimization. European Journal of Operational Research, 42 (3), 243-253.

Robichaud Y. (1975). Band resaws for sawing hardw,oods: a comparison between horizontal and vertical resaws. Can. Dept. Environ., Eastern Forest Prod. Lab. OPX 148E. 13 pp.

Schmidt, J. (2009). "Developments in Log Merchandising, Board Handling and Trimming Systems in the Sawmill" Catalogue. Springer Maschinenfabrik AG.http://www.springer.eu/fileadmin/do wnloads/Vortrag_SCJ.pdf

Singmin, M., NTRI (National Timber Research Institute - South Africa). (1978). SIMSAW: A simulation program to evaluate the effect of sawing patterns on $\log$ recovery. National Timber Research Institute, Council for Scientific and Industrial Research.

Sohrabi, P. (2013). A Three-stage Control Mechanism for the Lumber Production Process of a Sawmill Based on a Powers-of-two Modelling Approach. Master of Applied Science Thesis, Dalhousie University, Halifax, Nova Scotia, Canada.

Steele, P.H. (1984). Factors determining lumber recovery in sawmilling. US Department of Agriculture, Forest Service, Forest Products Laboratory.

Steele, P., Wade, M.W., Bullard, S.H., Araman, P.A. (1992). Relative kerf and sawing variation values for some hardwood sawing machines. Faculty Publications. Stephen F. Austin State University, Texas, 130.

Szymani, R. (1990). The latest developments in scanning technology and process optimization in the North American wood industry. Proceedings of the First European Wood Symposium "Wood and Computer Integrated Manufacturing: What is the Future?" Centre Technique du Bois et de l'Ameublement, Paris, France, May 1011.

Szymani, R. (1995). Latest Advances in Sawmilling. Serninario Internacional de Utilizacao da Maderia de Eucalipto para Serraria, Sao Paulo, Brazil, 5-6.

Tejavibulya, S. (1982). Dynamic programming sawing models for optimizing lumber recovery. Dissertation Abstracts International Part B: Science and Engineering, 42 (12).

Thomas, R.E. \& Thomas, L. (2013). Using parallel computing methods to improve $\log$ surface defect detection methods, Proceedings: 18th International Nondestructive Testing and Evaluation of Wood Symposium. General Technical Report FPL-GTR-226. Madison, WI: U.S. Department of Agriculture, Forest Service, Forest Products Laboratory. 808 p.

Todoroki, C.L. (1990). AUTOSAW system for sawing simulation. New Zealand Journal of Forestry Science, 20(3):332348.

Todoroki, C.L., Rönnqvist, E.M. (1997). Secondary log breakdown optimization with dynamic programming. Journal of the Operational Research Society, 48(5), 471-478.

Todoroki, C.L., Ronnqvist E.M. (1999). Combined primary and secondary log breakdown optimisation. The Journal of the Operational Research Society, 50(3):219-229. ISSN 0160-5682.

TS 276, (1980). Oak Sawlog. Turkish Standards Institution. Ankara, Turkey.

URL1, Massam (2016). Metal Legs for natural wood products, http://www.massam.com.tr/index.php/pr oject/soul-digital/

URL2, HALCO Software Systems Ltd. (2006). The SAWSIM Sawmill Simulation Program, http://www.halcosoftware.com/software/ index.html 
URL3, MWP (2016). CT scanning of timber to increase the product value. The Marcus Wallenberg Prize 2016, http://mwp.org/ct-scanning-of-timber-toincrease-the-product-value

URL4, Microtec-Springer (2016). Innovative wood processing solutions. http://springer-microtec.com/

URL5, Linck (2016). Manufacturer of Sawmill Line and Equipment,

http://www.linck.com/en/content/machines. html

URL6, The Wassmer Group (2016). Sawmill Technology, Log Band Saw, http://www.wassmer.de/en/saegewerkste chnik/log-band-saw/

URL7, Üstünkarlı (2016). Log Sawing Lines, http://ustunkarli.com.tr/

URL8, Wood-Mizer (2016). WM1000 Sawmill, http://www.woodmizereurope.com/Products/Industrial/Sawmill s/WM1000

URL9, (2016). EWD, The SawLine Company, http://www.ewd.de/en/technologyproducts/bandsaw-technology/bandresaw-systems/

URL10, (2016). Sawmill Hydraulics Inc. http://www.4helle.com/scragg_mills.htm

Zeng, Y. (1991). Log breakdown using dynamic programming and 3-D log shape. Master of Science Thesis, Oregon State University.

Zeng, Y. (1995). Integration of an expert system and dynamic programming approach to optimize log breakdown using 3-dimensional $\log$ and internal defect shape information. Thesis, Oregon State University. 